\title{
Konfliktscenarier ved Nordpolen
}

Af Martin Breum

De seneste års fortælling om Nordpolen og vores interessekonflikt med Rusland på klodens top er ganske uimodståelig. Den byder sig til som kalejdoskopisk udgangspunkt for spekulation og konstruktion af konfliktscenarier, og det kræver et rigt mål af ædruelighed at modstå fristelserne. En vifte af faktorer byder sig til, der alle er dynamiske og labile som soufflé.

Den russiske oprustning langs kanten af Det Arktiske Ocean er kontant, vedholdende og direkte forbundet med Vladimir Putins og hans regerings ambitioner om genvunden global storhed og militær overlegenhed i Nord. Det russiske krav om ejerskab til den arktiske havbund er på samme måde vedholdende og ambitiøst og i øvrigt baseret på Ruslands stolte tradition for arktiske erobringer, videnskabelig udforskning og suverænitetshævdelse.

Allerede i 1938 landede russiske piloter og forskere på selve Nordpolen, hvor de skrev luftfartshistorie og sam- tidig blev de første, der med moderne navigationsudstyr kunne dokumentere et ophold på polpunktet. Det var historisk. Russerne var de første på Nordpolen - uanset hvad Peary, Scott, Amundsen, Nansen, Nobile, Andreé og andre før havde bedrevet af luftfarter og andre forsøg. De russiske pionerer blev folkehelte og forstærkede en dyb russisk samhørighed med det arktiske, der stadig er gældende.

I nyere tid har forestillingerne om olie- og gasforekomster fundet frodig grobund i de arktiske kyststater, og tankskibe fragter nu mængder af olie til verdensmarkederne fra Gazproms Prirazlomnoye-platform i Pechorahavet. Kina har for længst købt billet til dette bonanza.

Samtidig gælder, at grænserne på havbunden ved Nordpolen i den internationale del af Det Arktiske Ocean stadig ikke eksisterer; vi ved ganske enkelt ikke, hvem der har ret til hvad i denne del af det globale. Det giver yderligere grobund for farverige konfliktscenarier.

Martin Breum er journalist og en af Danmarks førende iagttager af udviklingen i Arktis og af rigsfællesskabet. Han er forfatter til bl.a. 'Når isen forsvinder - Danmark som stortmagt i Arktis, Grønlands rigdomme og kampen om Nordpolen' og 'Hvis Grønland river sig løs - en rejse i kongerigets sprækker!' 
Stort set alle sikkerhedspolitiske analytikere, hvad enten de er amerikanske, russiske, danske eller af anden etnisk herkomst, har i en årrække været enige om, at der ikke er nogen reel udsigt til egentlige sammenstød eller militær uro.

Det dansk-grønlandske krav til havbunden ved Nordpolen blev indleveret til FN's Kommission for Kontinentalsoklens Grænser (CLCS) i december 2014. Det lyder på 985.000 kvadratkilometer - et område cirka 20 gange så stort som Jylland, Fyn og Øerne tilsammen. Potentielt er her tale om den største udvidelse af kongerigets rettighedssfære i nyere historie. Det modsvarende russiske krav, der blev indleveret til Sokkelkommissionen cirka et år senere, er endnu større, og de to krav overlapper med cirka 650.000 kvadratkilometer. Canada ventes at indsende et krav i 2019, der vil overlappe begge de to andre.

\section{Faste regler}

Vi taler med andre ord om et kontant og synligt sammenstød mellem det danske kongeriges og Ruslands interesser - og potentielt også Canadas. Her kan selv den blideste fristes til at male fanden på væggen, så lad os straks slå fast: Stort set alle sikkerhedspolitiske analytikere, hvad enten de er amerikanske, russiske, danske eller af anden etnisk herkomst, har $i$ en årrække været enige om, at der ikke er nogen reel udsigt til egentlige sammenstød eller militær uro i forlængelse af den interessekonflikt, der hersker mellem kongeriget Danmark, Rusland og Canada om retten til havbunden ved Nordpolen og videre ud i Det Arktiske Ocean.

FN's Havretskonvention, der blev vedtaget i 1982 og ratificeret af Danmark i 2004, indeholder et omfattende (og fænomenalt kompliceret) regelsæt netop for fredelig afklaring af retten til havbunden i internationalt farvand, og de regeringer, der har været involveret i striden om dette stykke havbund ved Nordpolen - inklusive den russiske har siden sagens begyndelse omkring årtusindskiftet gang på gang erklæret, at de agter at følge Havretskonventionens regelsæt til den dag, forhandlinger afsluttes i fred og fordragelighed.

Den sikkerhedspolitiske pointe er, at Rusland ved blot at følge Havretskonventionens bestemmelser står til at vinde retten til så kolossale dele af den arktiske havbund, at Danmark og alle andre i dette unikke tilfælde ifølge de fleste analytikere har al mulig grund til at tro det, når Rusland bedyrer, at man vil følge reglerne.

I efteråret 2018 fik jeg igen bekræftet denne analyse, denne gang hos en af Norges stærkeste Ruslandseksperter, seniorforsker Lars Rowe fra Fridtjof Nansens Institutt i Oslo. Vi mødtes i en af de gamle, maleribeklædte stuer på instituttet, indrettet i polarforskeren Nansens gamle pragtvilla i udkanten af Oslo. Nansen blev i 1922 FN's første højkommissær for flygtninge og fik samme år Nobels Fredspris for sin indsats for udvekslingen af 400.000 krigsfanger mellem Rusland, Tyskland og Østrig-Ungarn og for sin rolle under hungersnøden i Sovjetunionen i 1921. 
"Så længe udviklingen i Arktis foregår inden for havrettens rammer, vil Rusland se en fordel i samarbejdet, og der er ingen grund til at tro, at de øvrige kyststater skulle ønske at ændre på rammerne, for de nyder jo de samme fordele," sagde Rowe.

Alle fem arktiske kyststater kan i kraft af Havretskonventionen kræve ret til ressourcerne på og under den arktiske havbund i det omfang, havbunden hænger sammen med deres respektive landområder - også uden for de eksisterende eksklusive økonomiske zoner, der rækker 200 sømil ud fra kysterne. Den ret har kun kyststaterne, og da Rusland har en mere end $20.000 \mathrm{~km}$ lang kystlinje mod Det Arktiske Ocean, kan Rusland altså alene ved at følge reglerne vinde retten til kolossale dele af den arktiske havbund. De to andre interessenter ved Nordpolen, Canada og kongeriget Danmark, kan forvente lidt mindre dele af havbunden, men dog langt mere end alle de nationer på kloden, der intet får - deraf Rowes konklusion: De involverede i denne sag har stærk interesse i en fredelig udvikling, og Rusland mest af alle.

\section{Hvorfor så denne virak?}

Og hvorfor så alligevel denne rumlen i geledderne og mængder af historier i medierne om 'kapløb' og 'ny kold krig i Arktis'? Hvorfor fastholder Forsvarets Efterretningstjeneste stadig en væsentlig grad af usikkerhed og blå blink netop i analysen af de russiske forsikringer?

Først et blik på offentlighedens fascination. Nordpolen er omgærdet af århundreders mytologi, indskud og forestillinger fra stort set alle kulturkredse og fra de talrige polarfareres mange fortællinger. Som antropologen Kirsten Hastrup så fint gør rede for i Vinterens Hjerte - Knud Rasmussen og hans tid, var polarforskningen "den sidste store udfordring i oplysningstidens bestræbelse på at kortlægge verden. Nye videnskaber voksede frem (...) I slutningen af det 19. århundrede var der stadig ukendte strækninger at kortlægge, mulige passager at åbne og nye mennesker at finde i det arktiske". Polarforskerne havde i meget høj grad publikums opmærksomhed; Fridtjof Nansen gjorde i Nord $i$ Tåkeheimen ligefrem jagten udi det arktiske til noget nær oplysningens kerne:

"Hvorfor tog vi tilbage? Der mod nord i mørke og kulde stod Helheim, dødens bolig, hvor dødsgudinden herskede, der lå Nåstrand, ligstranden - der hvor intet levende vosen kunne ånde; der ind søgte det ene hold efter det andet - hvorfor? For at hente døde hjem? - ligesom Hermod, da han red efter Balder? Nej, kundskab for kommende sloegter var det de hentede - og vil du se menneskeånden i dens cedleste kamp mod overtro og mørke, da loes de arktiske rejsers historie, loes om moend, som $i$ tider, da overvintring i polarnatten me-

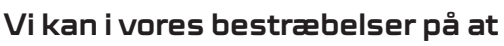
forudsige udviklingen i Arktis forsøge at holde os til fakta, men vi bliver konstant ledt på afveje af vores indre billeder af et Arktis fra fortiden; mere eller mindre vederhæftige aflejringer, myter og røverhistorier. 


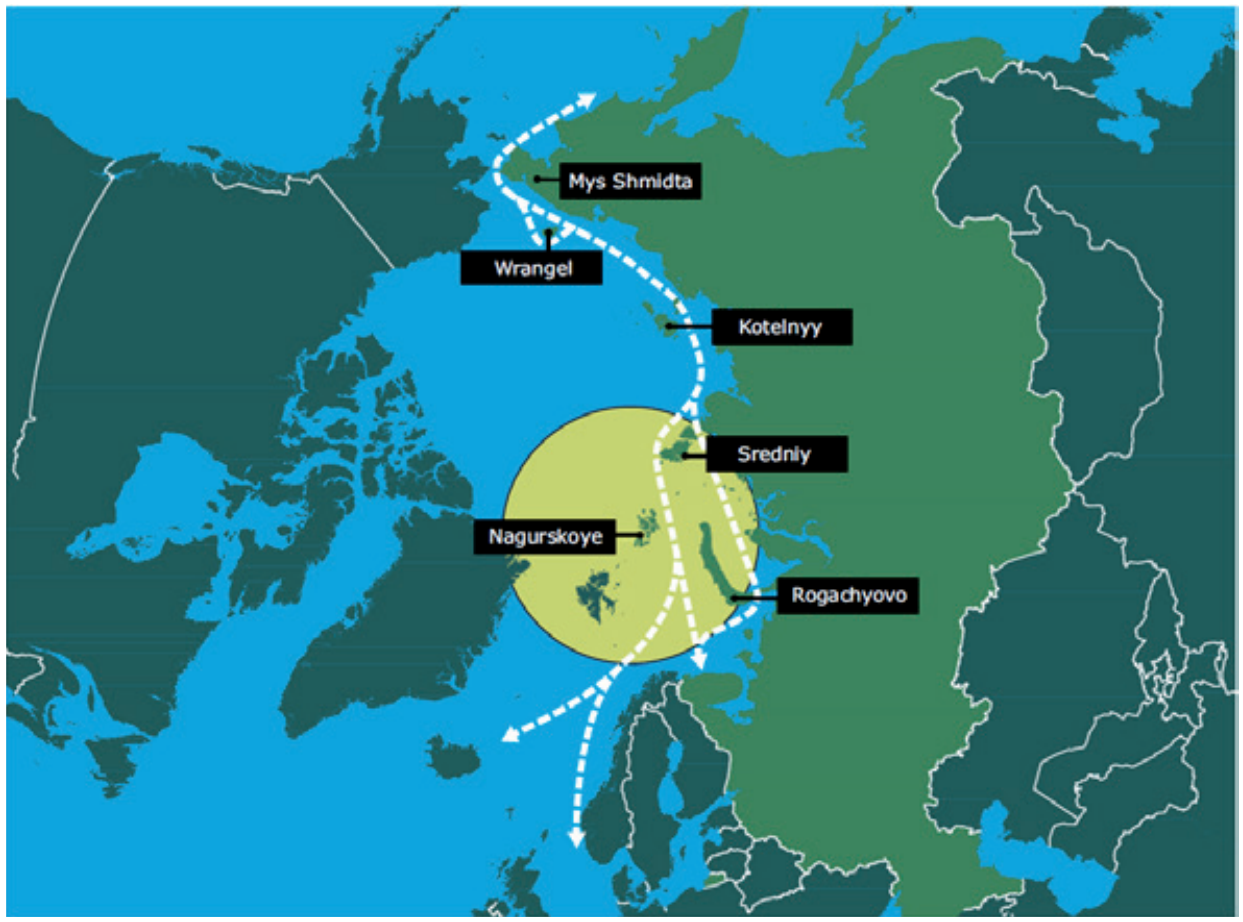

ILL: Kortet viser Rusland seks fremskudte baser

Det russiske forsvar har i de seneste år genopbygget eller nyoprettet en række militære installationer, inklusive luftbaser, langs den russiske nordkyst. De gule cirkler viser jagerflys rækkevidde fra disse baser. Med optankning i luften øges rækkevidden betragteligt, og flyene vil nu på kort tid kunne nå f.eks. den amerikanske Thule-base i Grønland. Hertil kommer den russiske Nordflådes styrker og arsenaler, inklusive nye missilbærende ubåde på flådebaserne på Kolahalvøen. Den russiske genoprustning i Arktis skyldes bl.a. et behov for øget sikkerhed for olie- og gasinstallationer og den tiltagende fragtsejlads i Nordøstpassagen. Passagen ses som hvide striber på kortet.

Kilde: Efterretningsmæssig Risikovurdering 2018, Forsvarets Efterretningstjeneste.

re sandsynligt gav død end liv, dog med flyvende faner drog ud til det ukendte." Vi kan i vores bestræbelser på at forudsige udviklingen i Arktis fors $\varnothing$ ge at holde os til fakta, men vi bliver konstant ledt på afveje af vores indre billeder af et Arktis fra fortiden; mere eller mindre vederhæftige aflejringer, myter og røverhistorier. Selv naturvidenskabsmanden Fridtjof Nansen lod sig betage og lede af polpunktets fascinationskraft. I 1890 indledte han den legendariske, treårige færd, hvor han lod sit tremastede skib Fram fryse fast i pakisen og drive hen over Det Arktiske Ocean for at bevise isens drift. Forud hævdede han i Kristianias Geografiske Selskab, at Nordpolen var ham uvedkommende: "det er ikke for at søge det matematiske punkt, som danner jordaksens nordlige endepunkt, at vi er draget ud; thi at nå dette punkt har i og for sig kun ringe voerd; men det er for at anstille undersøgelser i den store ukendte del af jorden som omgiver polen, og de undersøgelser vil have om- 
trent lige stor videnskabelig betydning, enten foerden går over selve polpunktet eller et stykke fra det," sagde han.

Senere midt under FRAM-ekspeditionen plagedes Nansen og hans besætning af tung kedsomhed $i$ isen, og nu vendte han det hele på hovedet. $\mathrm{Da}$ Nansen opdagede, at havstrømmene ikke som ventet ville føre dem hen over selve Nordpolen, ændrede han planer. I sit store tobindsværk om færden med Fram beskrev han, hvordan en uimodståelig drift mod polen rev i ham, plagede ham, nagede ham, groede i ham, til han endelig måtte give efter:

"For en lyst! Når jeg ser ud over isen $n u$, er det som om, det dirrer i musklerne af loengsel efter at få lov at sæette af sted over den for alvor - anstrengelser og savn, alt skal da blive en nydelse. Det kan synes naragtigt, at jeg vil ud på denne ford; her var måske vigtigere ting at udføre med noget roligt arbejde om bord. Men polen er nu engang et mål som loenge har vinket til mennesket. Gør vi ikke forsøget nu, når vi er så langt mod nord, kan det hoende, at der går en rum tid igen."

Fridtjof Nansen lod skib være skib og begav sig med kun en enkelt følgesvend og et kobbel hunde af sted mod Nordpolen. Han vidste, at distancen var adskillige hundreder kilometer, og at turen ville være livsfarlig, men det stoppede ham ikke. Han måtte. Og han gjorde det.

Turen mislykkedes. Forfrossen og overmandet af isen måtte Fridtjof Nansen og kollegaen vende om, længe før de nåede Nordpolen, men for os andre, der nu skal afkode nye arktiske erobringstogter, fik de for altid anskueliggjort, hvor stærkt det imaginære kan være selv når vi tror os mest løsrevet fra det.

\section{Flaget på bunden}

Jeg vil påstå, at vi er nødt til at have denne dimension med, når vi forsøger at forstå den offentlige samtale om Nordpolen, når vi følger diplomatiet, og når vi forsøger at bestemme, om de russiske forsikringer holder. Også politikere, militære strateger og diplomater er rundet af historiske erfaringer, og netop når det gælder det arktiske, vil de involveredes aktuelle, faktuelle viden til tider af historiske og logistiske årsager være begrænset. De tre forfattere, Steinberg, Tasch og Gerhardt påviste i Contesting the Arctic-politics and imaginaries in the circumpolar North, hvordan diplomater og politikere i de arktiske lande på overfladen alle synes at følge en fælles strategi om bæredygtig udvikling, men de dokumenterede også, at der under overflade findes mindst syv forskellige dominerende narrativer om, hvad Arktis er for en størrelse.

I efteråret 2018 kortlagde den svenske miljøhistoriker Sverker Sörlin og en række andre i Competing Arctic Futures - historical and Contemporary Perspective, hvordan alskens forudsigelser om fremtiden i Arktis ofte er baseret på forenklede perspektiver - i øjeblikket er det isens forsvinden og klimaets forandring, der dominerer, mens de arktiske folkeslags og andre aktørers almindelige, demokratiske handlinger og visioner fortrænges.

Der er med andre ord ganske meget at tage højde for, hvis vi skal forstå diskussionen om kontinentalsoklen. 


\section{Nordpolens mytiske kvaliteter og iboende fortællinger om heltedåd og patriotiske indsatser for konge og fædreland er en konstant karakter i fortællingen, mest notorisk illustreret ved den russiske flag- plantning ved Nordpolen i august 2008.}

de rejsende var på vej hjem, mens Ruslands udenrigsminister Sergei Lavrov fastholdt, at dykket blot var en teknisk bedrift, præcis som da amerikanerne landede på månen. Lavrov forkla-

Nordpolens mytiske kvaliteter og iboende fortællinger om heltedåd og patriotiske indsatser for konge og fædreland er en konstant karakter i fortællingen, mest notorisk illustreret ved den russiske flagplantning ved Nordpolen $\mathrm{i}$ august 2008.

Her dykkede to russiske miniubåde 4300 meter ned til bunden af Det Arktiske Ocean præcis ved Nordpolen på 90 grader nord. Et livsfarligt, spektakulært stunt anført af den 67-årige polarforsker Artur Nikolajevitch Tjilingarov. Han var på det tidspunkt næstformand for Dumaen og tæt på Ruslands præsident, Vladimir Putin.

Vel ankomne til bunden plantede de rejsende med en robotarm og for rullende kameraer en godt én meter høj russisk trikolore i platin. For Tjilingarov drejede det sig om at gøre Nordpolen russisk. Det arktiske islandskabs mytiske epicenter hører i Artur Tjilingarovs og mange andre russeres optik selvfølgeligt med til Ruslands arktiske sfære.

Dykket udløste alarm i hele verden også i København. Var ubådsaktionen styret fra Kreml af Vladimir Putin? Var aktionen bevis på, at Rusland spiller et rænkespil, hvor politikere og slebne diplomater taler om fred, mens Moskva overvejer mere kontant magtanvendelse ved Nordpolen? Vladimir Putin hyldede ekspeditionen allerede, mens rede, at det mudder, ubådene hentede op fra havbunden, indgik i den videnskabelige dokumentation for Ruslands krav på havbunden helt i overensstemmelse med Havretskonventionen.

Politolog Morten Larsen Nonboe, der gravede sig ned i sagen, konkluderede i 2010, at dykket ikke mindst var tænkt som middel til at illustrere den russiske stats styrke over for den russiske offentlighed. Men det viste også, grupper internt i Moskva kæmper om den russiske Arktispolitik. Artur Tjilingarov repræsenterede de nationalistiske grupperinger i Moskva, mens Lavrov hører til den mere pragmatiske fløj, der tilsyneladende er klar til de kompromisser, der måtte følge på Havretskonventionens vej.

Analytikerne i Forsvarets Efterretningstjeneste indfanger en række af disse komponenter - også det imaginære - i deres trusselsvurdering for 2019 (offentliggjort ultimo 2018). Jeg tager her næsten det hele med, så de finere nuancer ikke udviskes:

"Selvom sokkelspørgsmålet formelt drejer sig om retten til at udnytte ressourcerne i havbunden, er det meget sandsynligt, at det for Rusland først og fremmest handler om sikkerhed, identitet og prestige. Det er således sandsynligt, at Rusland ser sikkerhedspolitiske fordele ved at fä ret til at udnytte skrev han, hvordan konkurrerende 
så stor en del af kontinentalsoklen som muligt, da dette kan understøtte russiske argumenter om at styrke den militore tilstedevoerelse og kapacitet $i$ området. Tilsvarende er det sandsynligt, at Rusland frygter, at NATO-lande vil kunne patruljere i farvandet toet $p a ̊$ Rusland, hvis et NATO-land fär ret til at udnytte ressourcerne $i$ kontinentalsoklen toet på grcensen til Rusland. Sokkelspørgsmålet har stor betydning for Ruslands fors $\varnothing g$ på at fremstille sig selv som den førende arktiske stormagt. Hvis gronserne skulle ende med at blive trukket toet $p a ̊$ Ruslands 200-sømilegronse, vil Rusland derfor se det som et stort prestigetab. Rusland er utilfreds med omfanget af Danmarks krav, som går helt til Ruslands 200-sømilegroense. Det er sandsynligt, at kravet har givet noering til de interne spoendinger om Ruslands samarbejdskurs $i$ Arktis. Til trods for utilfredsheden med det danske krav er det dog stadig Ruslands politik at forhandle sig frem til en gronse i overensstemmelse med den internationale havrets regler. Rusland, Danmark og Canada forventes at starte egentlige forhandlinger om en foreløbig græense, efter at Canada har indleveret sit krav til sokkelkommissionen. Det er dog muligt, at Rusland vil fors $\varnothing$ ge at loegge politisk og diplomatisk pres på Canada og Danmark for at forlade FN's sokkelkommission som rammen for forhandlinger om gronserne, hvis Rusland mener, at FN-forhandlingerne går den forkerte vej for russiske interesser."

\section{Ingen fisk}

FE bliver her dejlig politisk. Som det fremgår, drejer sagen sig alene om retten til ressourcerne på eller under havbunden - olie, gas, mineraler, krabber osv. De involverede nationer vinder ikke retten til vandsøjlen i Det Arktiske Ocean, fiskene, hvalerne eller luftrummet over havoverfladen. De vil kun i begrænset (omend stadig uafklaret) omfang vinde retten til at regulere trafikken på havoverfladen. Danmark vil eksempelvis med god ret formentlig kunne forhindre andre nationer $\mathrm{i}$ at bore efter olie i den havbund, der tilfalder det danske kongerige, men der vil næppe være hjemmel til fx at holde krydstogtsskibe eller fiskefartøjer væk.

Alligevel vurderer FE altså, at Rusland vil gå langt for at sikre sig retten til så store områder af havbunden, at Ruslands tanker om sig selv som 'førende arktisk stormagt' bliver tilfredsstillet. FE vurderer endog, at denne ambition kan føre til brud på Ruslands efterlevelse af Havretskommissionens regler. Analysen placerer os potentielt alene og frysende på Herrens mark eller rettere der, hvor den russiske uforudsigelighed, som vi kender den fra Ukraine, Krim, Syrien og Baltikum, pludselig bliver særdeles relevant også i Arktis.

Kommer det til at gå så galt? Er det sandsynligt, at FN's Sokkelkommission vil vurdere, at den nye grænse for Ruslands ret til havbunden i Det Arktiske Ocean bør trækkes så tæt på Ruslands eksisterende 200-sømilegrænse, at Rusland begynder at frygte, at NATO vil benytte lejligheden til markant at øge sin patruljering i Det Arktiske Ocean og dermed true Ruslands arktiske styrkeposition? Og vil NATO reelt være fristet til at (mis)bruge en sådan situation 
til at placere krigsskibe tæet på Ruslands arktiske farvande?

Her kan man næsten selv efter behag digte videre.

Lidt enklere er det i den rent danskgrønlandske forbindelse: Her er det i sidste ende primært Grønland, der kan få økonomisk gavn af processen. Alle værdier i Grønlands undergrund tilhører ifølge Selvstyreloven fra 2009 det grønlandske folk (efter udligning af bloktilskuddet). Det betyder, at eventuelle fund under den del af havbunden i Det Arktiske Ocean, der måtte tilfalde det danske konge-

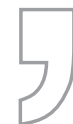

I København frygter man, at Rusland dernæst i en årrække vil vænne sig til at kalde Nordpolen russisk, før en afklaring af det dansk-grønlandske krav foreligger. på Nordpolen). rige, primært vil forbedre den grøn-

landske økonomi. Geologerne har ikke endnu påvist nogen reel udsigt til hverken olie, gas eller mineraler i de dele af oceanet, vi taler om her, men skulle man alligevel ad åre finde et eller andet af værdi, vil gevinsten altså være grønlandsk mere end dansk.

\section{Hvem gør hvad hvornår?}

Proceduren er værd at forstå. Rusland og kongeriget Danmark har som nævnt allerede indsendt krav til FN's Sokkelkommission. (Kravene kaldes formelt submissioner. I juridisk forstand er der ikke tale om krav, men alene om videnskabelige data om den arktiske havbunds beskaffenhed.) Canada ventes at indsende sin submission i 2019. (Det dansk-grønlandske krav på havbunden nord for Grønland overlapper på et mindre område Norges krav nord for Svalbard, men Nor- ge gør ikke krav på havbund tættere

De 21 geofysikere med videre i FN's Sokkelkommission forventes at vurdere de tre submissioner inden for fem til ti år. En stribe nationer står i kø til behandling hos kommissionen, så tingene går umådeligt langsomt. Ruslands krav vil blive behandlet først, fordi Ruslands oprindelige submission blev afleveret allerede i 2001. I København frygter man, at Rusland dernæst $\mathrm{i}$ en årrække vil vænne sig til at kalde Nordpolen russisk, før en afklaring af det dansk-grønlandske krav foreligger. Det kan angiveligt gøre det vanskeligt for de danske diplomater at vende billedet, selvom Sokkelkommissionen ad åre også skulle give Danmark ret.

Her kommer overlappene ind. Hvorfor kan flere krav på Nordpolen - eller andre dele af havbunden -være lige gode? Jo; hænger havbunden i Øresund måske ikke sammen med Sverige? Og med Danmark? Svaret er i begge tilfælde ja - og sådan ser det muligvis også ud på Nordpolen. Vi ved ikke, i hvilket omfang de tre krav ved Nordpolen reelt overlapper, før Sokkelkommissionen har talt.

Kommission vil evaluere de indsendte videnskabelige data. Dernæst meddeler kommissionen i hvilket omfang, de tre nationer har dokumenteret, at havbunden under Det Arktiske Ocean hænger sammen med kontinentalsoklen under deres respektive landområder. I kongerigets tilfælde handler 
det om sammenhængen mellem oceanets bund i den ene ende og det grønlandske grundfjeld i den anden. Når den sag er afklaret, er det op til diplomaterne fra Asiatisk Plads at bide skeer om selve grænsedragningen med modparterne fra Ottawa og Moskva.

Disse forhandlingerne vil gå i gang lang tid før, Sokkelkommissionens vurdering foreligger, sådan som det også fremgår af FE's analyse - nemlig så snart Canadas krav er kendt. Danske, russiske og canadiske diplomater har i en årrække holdt samling en gang om året for at sikre, at sagen udvikler sig til fredeligt, og der er enighed om, hvordan forhandlingerne skal forløbe. Forståelsen afspejler tilsvarende forhandlinger om et stykke havbund nord for Færøerne, hvor Norge, Island og Danmark/Færøerne havde overlappende krav, og hvor man forhandlede en foreløbig grænse på plads, før den endelige vurdering fra Sokkelkommissionen forelå. I heldigste fald vil en sådan forhandling ikke bare trække en foreløbig grænse på havbunden, men også fastlægge præcis, hvordan denne grænse skal justeres, såfremt Sokkelkommissionens endelige vurdering viser, at et eller flere af landene har været for optimistiske, da de indsendte krav.

Når staterne i sidste ende ikke til enighed, kan sagen overlades til en international domstol, mest sandsynligt den internationale i Haag.

\section{Canada brød aftale}

Som FE skriver, er der allerede fortørnelse i Moskva over det kolossale dansk-grønlandske krav, og histo-
Målet blev nu at skaffe data om et langt større stykke havbund - også fra områder uden for dem, forskerne havde besøgt på tre isbryderekspeditioner og andre dataindsamlinger.

rien rummer også en seriøs konflikt med Canada. De danske forskere, der forestod dataindsamlingen i Det Arktiske Ocean, foreslog i første omgang et relativt beskedent dansk-grønlandsk krav. De mente, at Danmark og Grønland var godt rustede til at dokumentere et krav på cirka 155.000 kvadratkilometer - rundt regnet fra grønlandsk farvand til Nordpolen.

I den politiske proces, hvor Nuuk og København skulle enes, var det dog langt fra tilstrækkeligt, og forskerne måtte tage fat igen. Målet blev nu at skaffe data om et langt større stykke havbund - også fra områder uden for dem, forskerne havde besøgt på tre isbryderekspeditioner og andre dataindsamlinger. En kompliceret søgning, der omfattede åbne kilder på internettet og data fra amerikanske ubåde, gik i gang.

I samme periode valgte regeringen i Canada at bryde en aftale med Danmark. Ottawa og København havde med formelle noter aftalt, hvordan de to nationers krav til FN skulle afgrænses langs en linje lige langt fra Grønland og Canada.

Canada brød denne aftale, da den canadiske premierminister Stephen Harper opdagede, at det canadiske krav ikke ville omfatte selve Nordpolen. I København førte det til gevaldig utilfredshed; statsminister Helle Thornings Schmidt affyrede angiveligt en officiel klage til Harper - dog uden 
for offentlighedens lys - og politikerne i Grønland og Danmark fik ny anledning til at overveje, hvordan kravet til FN skulle se ud.

Arbejdet var færdigt $\mathrm{i}$ december 2014. Tre flyttekasser med data blev afleveret til FN i New York. Danmark og Grønland mente nu at kunne dokumentere kongerigets ret til ressourcerne på og under 895.000 kvadratkilometer af havbunden i Det Arktiske Ocean- inklusive havbunden ved selve Nordpolen. Vi kender ikke det præcise, politiske ræsonnement bag dette krav, men alt tyder på, at den danske regering, repræsenteret ved udenrigsminister Martin Lidegaard, og det grønlandske landsstyre ved formanden Aleqa Hammond var enige om, at rigets position forud for forhandlingerne med Rusland og Canada ville forbedres jo større krav, man stillede fra start. Man varslede Rusland forud for offentliggørelsen, så officielle vredesudbrud blev afværget, men det er altså nu velkendt, at kravet ikke er populært i Moskva.

\section{Verdensarv?}

I folkerettens forstand spiller Nordpolen - altså det geografiske punkt på 90 grader nord midt i Det Arktiske Ocean - sjovt nok ingen som helst rolle. De russiske, danske og canadiske diplomater har intet særligt mærke på dagsordenen, hvor der står NORDPOLEN, selvom alle ved, at selve polpunktet spiller en væsentlig symbolsk rolle ikke mindst i Rusland.

Ingen i kongerigets officielle rækker synes heller at overveje, om selve polpunktet måske burde tildeles værdi og beskyttelse som kulturel immateriel verdensarv. UNESCO har så vidt vides ikke på noget tidspunkt været inddraget i de danske overvejelser - og ej heller i de russiske eller canadiske. Det er velkendt, at forestillinger om Nordpolen fra tidernes morgen har spillet en væsentlig rolle for menneskets forståelse af verden, men det faktum indgår tilsyneladende ikke på nogen vis i de aktuelle overvejelser.

Når Nordpolen alligevel i de seneste år har sneget sig ind i retorikken bag kongerigets krav til FN, afspejler det i øvrigt mere et dansk ønske end et grønlandsk. Det var danske ministre ikke mindst forhenværende udenrigsminister Per Stig Møller - der først talte om, at Nordpolen burde være dansk. Ingen i Grønland har udtrykt samme trang; tidligere landsstyreformand Kuupik Kleist argumenterede tværtom for international fredning af et udefineret stykke vand rundt om Nordpolen. Den ide fik kyndige embedsmænd i Lene Espersens tid som udenrigsminister skubbet effektivt af vejen - og Kuupik Kleist har ikke længere politisk embede.

Thule-eskimoerne kaldte i sin tid Nordpolen for Qalasersuaq, den store navle. Denne mystiske lokalitet lå hinsides menneskenes land, hvor kun åndemanerne kunne komme. Qalasersuaq var ikke et rart sted, snarere et 
farligt dyb, de uforsigtige kunne falde i, og da Frederik IV's udsendte i 1730 ville til Nordpolen, forsøgte de uden held at overtale grønlændere til at vise vej. Knud Rasmussen beskrev senere, hvordan grønlændere dyrkede helteforestillinger om thuleeskimoerne i nord. Men det var forestillinger om mennesker af kød og blod - ikke om Nordpolen. I beretningen fra Den litterære Grønlandsekspedition i 1903, hvor bl.a. Mylius-Erichsen og Knud Rasmussen deltog, citeres fangeren Marsanguak fra Thule-distriktet for en betragtning om amerikaneren Robert Peary, der så gerne ville til Nordpolen:

"Han alene ville tronge loengst mod Nord, bort fra Landene, det var nu hans Lyst, endda vi synes, den er moerkelig, for deroppe lever jo sletingen Dyr og bor ingen Mennesker og er bare Is, og intet Land at se. Men saadan har hvert Menneske sin Sorhed."

Vil indtagelsen af Nordpolen yderligere 'deflorere Nordens utilgængelighedsmyte', som forfatteren Jens Christian Grøndahl skrev i Weekendavisen? Kan man ustraffet koble Nordpolen til en enkelt nation, eller rykker man der- med urimeligt ved kommende generationers oplevelse af det mytiske ved Nordpolen og det arktiske? Har den danske regering en holdning til det store isødes betydning for 'menneskehånden i dens ædleste kamp mod overtro og mørke?' som Fridtjof Nansen skrev om? Rejser klimaforandringerne og polarisens forsvinden nye spørgsmål, der kræver svar? Bør havet omkring Nordpolen fredes, som miljøorganisationerne hævder, og i givet fald i hvilket omfang? Af hvem og under hvis kontrol?

Hvis der foreligger dybere tanker fra politisk hold i Danmark eller Grønland om disse spørgsmål, er de fortsat ikke offentliggjort. Kongeriget har formuleret sit krav og udnyttet Havretskonventionens muligheder til det absolutte maksimum. Den præcise begrundelse kender vi ikke, men princippet synes at være, at man tager, hvad man kan, fordi man ikke ved, hvad man ellers går glip af.

En lang forhandlingsproces forestår - og altså også risikoen for forviklinger som beskrevet af FE. 